\title{
DIZER-SE, AUTOGRAFAR-SE: EVOCANDO MÁRIO CESARINY
}

\author{
TO SAY AND TO AUTOGRAPH ONESELF: \\ EVOKING MÁRIO CESARINY
}

Maria Silva Prado Lessa ${ }^{1}$

\section{RESUMO}

Em sua obra escrita, Mário Cesariny recorre à metalinguagem característica das artes poéticas para nela inscrever uma reflexão acerca das figurações do poeta e da potência criadora da palavra poética. Dobrando-se sobre si mesmos, seus poemas se abrem a uma dinâmica na qual a voz poética simultaneamente tem e não tem origem naquele que se lança à escrita. Este artigo se ocupa da leitura de três poemas de Cesariny nos quais o autoendereçamento ou a autodescrição emergem como temas principais, articulando-os a textos de T. S. Eliot, Éric Benoit e Dominique Combe que se ocupam do problema origem da voz poética.

PALAVRAS-CHAVE: Literatura portuguesa; poesia contemporânea; Mário Cesariny

\section{ABSTRACT}

In many of his poems, the surrealist Mário Cesariny employs metalinguistic structures common in what we call "ars poeticas" seeking to reflect upon the different representations of the poet and the power of the poetic verb. The poems seem to fold over themselves, installing a dynamic in which the poetic voice simultaneously has and has not its origin in the poet himself. This article focuses on three poems by Cesariny that have either "self-addressing" or "self-description" as their main theme, in dialog with texts by T. S. Eliot, Éric Benoit and Dominique Combe that focus on the poetic voice's origin.

KEYWORDS: Portuguese Literature; Contemporary Poetry; Mário Cesariny 


\section{QUEM FALA?}

Na seção "Les hommages excessives" do livro Primavera autónoma das estradas (2017 [1980]), Mário Cesariny incluiu poemas em francês endereçados a diversos artistas, cujos títulos seguem uma mesma fórmula de dedicatória, como em "À André Breton", "À Victor Brauner" e "À Alexandre O'Neill”. Na epígrafe da publicação, encontra-se uma citação de Novalis na qual defende a importância de se escrever "em comum", de se retomar e invadir o trabalho alheio como forma de criação de uma obra: “O 'escrever em comum' é um sintoma curioso que faz prever um grande aperfeiçoamento na arte da escrita. Talvez cheguemos a poder escrever, pensar, agir em comum. Comunidades inteiras, e mesmo nações poderão empreender uma obra" (NOVALIS apud CESARINY, 2017, p. 455). Com a retomada do romântico alemão, Cesariny defende um modo de estar em constante leitura da obra alheia e de encontrar o outro por meio do fazer artístico. Recorre, assim, a um mecanismo utilizado desde os primeiros anos de sua produção poética, com Corpo visível, em 1950: dirigir-se a um outro e o buscar por toda a parte - seja ele uma obra alheia convidada a dialogar com a sua própria, seja ele um tu que se revela como amante e leitor, companheiro indispensável para a produção da obra.

Em meio aos poemas dedicados a outros artistas, há dois textos em homenagem a ninguém menos que o próprio Cesariny. Trata-se dos poemas intitulados, ambos, "À moi-même":

\section{À MOI-MÊME}

pour louise soleil-devinette je double $\mathrm{v}$ un moment pour les amis qui sont morts je pourrais pleurer ci-devant mais pour tous ceux qui ont tort je vais t'arracher les dents (CESARINY, 2017, p. 475)

\section{À MOI-MÊME}

il se promène sous écorce d'arbre il parle aux femmes de ce qu'on apelle minoir il a acheté un porte-bonheur très souple il couche avec quand il va tout seul (CESARINY, 2017, p. 476).

O autoendereçamento que lemos nos versos de Mário Cesariny parece ecoar a tripartição da voz poética proposta por T. S. Eliot em seu "As três vozes da poesia" que, para definir modos de enunciação poética, parte da descrição dos distintos interlocutores a quem o poeta endereça sua fala, pautando-se em sua própria experiência como poeta e dramaturgo. Expondo sua divisão das vozes de acordo com as distintas funções a serem eleitas diante das intenções comunicativas do autor, apresenta a primeira 
Voz como sendo "a do poeta falando para si mesmo" (ELIOT, 1998, p. 97), a segunda como aquela que soa quando este se dirige a um auditório e a terceira como a que emerge quando transpõe sua voz para um personagem dramático, "quando ele diz, não aquilo que pessoalmente nos diria, mas aquilo que lhe é possível dizer adentro dos limites de uma personagem imaginária que se dirige a outra personagem imaginária” (ELIOT, 1998, p. 97).

Apesar de Eliot tentar se distanciar dos termos "lírico", "dramático" e "épico", sua teoria das vozes parece devedora da leitura romântica da "tripartição retórica 'pseudoaristotélica" (COMBE, 2010, p. 114) dos gêneros literários, conforme apresentada por Dominique Combe em "A referência desdobrada: o sujeito lírico entre a ficção e a autobiografia". Ao analisar o campo crítico de discussão da relação entre ficção e autobiografia em poesia, Combe defende que a divisão dos discursos poéticos em "lírico", "dramático" e "épico" proposta pelos românticos alemães se pautava pela "distinção gramatical entre as pessoas", sugerindo que "a poesia lírica é essencialmente 'subjetiva', em função do papel predominante que ela confere ao 'eu', enquanto a poesia dramática é objetiva (tu/você), e a épica, 'objetivo-subjetiva' (ele)" (COMBE, 2010, p. 114). De maneira similar, para Eliot, a primeira voz, a qual soa quando o sujeito fala de si para si, estaria ligada ao discurso lírico, uma vez que nela predomina o "eu" do poeta, ou a "origem" do poema; a segunda voz, por ser o endereçamento a um ouvinte, liga-se ao discurso épico; e a terceira, pelo fato de emergir na fala de um personagem criado por um poeta, relaciona-se ao discurso dramático. Identificando o poema lírico como aquele que "expressa diretamente os pensamentos e sentimentos do próprio poeta”' (ELIOT, 1998, p. 110), o escritor britânico une, em seu conceito de primeira voz, o autor que efetivamente escreve o poema ao sujeito que nele se enuncia. Apoia, portanto, na "diferença entre uma pessoa falar por si e falar por uma personagem imaginária" (ELIOT, 1998, p. 102, grifos nossos), a distinção entre a primeira e a terceira voz, respectivamente. Nesse ponto, pode-se perceber como a definição eliotiana de primeira voz tende a uma leitura referencial do discurso poético, desejando estabelecer com "clareza a linha que vai do poema até às suas origens" (ELIOT, 1998, p. 112). A oposição que sugere entre a primeira e a terceira voz se aproxima, assim, de uma concepção romântica de sujeito poético, descrito por Combe como uma manifestação sincera de um poeta que se "confessa", expondo o seu "eu" verdadeiro.

Os poemas de Cesariny transcritos acima parecem se aproximar da manifestação da primeira voz de Eliot pelo fato de apresentarem um poeta falando de si e a si mesmo, conforme é explicitado, de partida, por seus títulos. Garantindo a homenagem e estabelecendo um endereçamento de um sujeito a um outro, a expressão "A Fulano" - que aparece em todos os poemas da seção do livro, como "À André Breton" ou "À Alexandre O’Neill” -, como paratexto, é utilizada no espaço da "perigrafia” (COMPAGNON, 1996, p. 105), uma "zona intermediária entre o fora do texto e o texto [...] [que] testemunha o controle que o autor exerce sobre ele" 
(COMPAGNON, 1996, p. 105), garantindo certo grau de "extraliterariedade" que provoca a sensação de que é o autor mesmo quem fala. Nesse ponto, a expressão "a mim mesmo" implica uma coincidência entre o autor responsável pela escrita do poema, o sujeito que nele se expressa e o destinatário a quem se dirige.

No primeiro, ainda que suas ações sejam condicionadas por outros - por "louise soleil-devinette", pelos "amis qui sont morts" e por "tous ceux qui ont tort" -, o sujeito que se anuncia no título reaparece no pronome "je", repetido a cada dois versos, e na utilização dos verbos conjugados na primeira pessoa do singular. A imbricação de referentes se agrava, contudo, ao se observar a ocorrência de um "tu" no último verso, pois, se, até aquele momento, o sujeito que se dirigia a si mesmo se limitava a descrever suas ações, a partir do momento em que afirma "je vais t’arracher les dents", recorrendo ao uso do pronome de segunda pessoa do singular ("tu"), o eu lírico tanto se dirige ao poeta que de fato escreve o poema quanto àqueles que o leem, num movimento que lança a voz do poema para fora das páginas escritas e a presentifica no ato de leitura. $\mathrm{O}$ "tu" que terá os dentes arrancados passa a ser, nesse momento, o leitor que é incluído como personagem na cena do poema. Na composição seguinte, os versos que se seguem ao título parecem teatralizar o processo de desdobramento do eu lírico e do destinatário do poema, processos lançados por Eliot ao terreno da terceira voz. A descrição de uma terceira pessoa provoca a passagem da autodescrição do poeta, lida na página imediatamente anterior, para uma descrição objetiva de um outro, fazendo com que o autoendereçamento anunciado pelo título do poema não seja confirmado. Há um descompasso, assim, entre o sujeito que se apresenta no título e aquele que se encontra nos quatro versos que constituem o poema, num descolamento entre o "eu" que fala a "si mesmo" e o "ele", seu objeto.

Dedicar um texto a si mesmo consiste em, simultaneamente, reconhecer-se como um artista que se quer inserido numa corrente de "escrita em comum" e atestar a sua transformação num outro por meio do fazer artístico. A opção pela escrita em francês contribui para o processo de distanciamento entre o poeta e ele mesmo e de transformação da própria voz em uma outra. O sujeito que a si se dirige é, assim, capaz de lançar sua voz para fora de seu corpo para a ouvir como se fosse uma voz alheia. Dessa forma, se o próprio poeta é transformado em um outro, em um personagem de si mesmo que lhe (se) diz a sua identidade, é possível observar uma distinção fundamental a separar a manifestação da primeira voz de Eliot e aquela que se anuncia nos poemas de Cesariny: os autores se aliam a conceitos distintos de sujeito poético. Em "As três vozes da poesia", a primeira voz une poeta a eu lírico, identificando naquele a "origem" da voz, ao passo que, nos poemas de Cesariny, há uma recusa da posição de anterioridade de seu autor em relação à obra, oferecendo às vozes enunciativas dos poemas a possibilidade de descreverem a sua própria identidade 
a cada verso. Dessa maneira, percebe-se um deslocamento do poeta como um a priori do poema, um sujeito "pré-poemático", e a emergência de um outro, a posteriori, efeito de poesia.

Ainda que Eliot reconheça na primeira voz um menor investimento dramático, a exposição do imperativo da escrita poética - pressuposto dessa voz - parece conferir à poesia um efeito performático e teatral. Assim, para que seja possível caracterizar a primeira voz, é significativo que Eliot recorra à descrição do processo de escrita em que ela emerge, da cena em que o poeta ainda busca o alívio prometido como recompensa pela produção do poema, fato que reforça a ideia de progressão que subjaz à manifestação dessa voz. Falando que "oprime-o [o poeta] um peso que ele deve dar à luz para conseguir alívio" (ELIOT, 1998, p. 112), defende que

todo o esforço do poeta não é para comunicar com ninguém, mas para conseguir alívio de um profundo incómodo; e quando as palavras estiverem por fim convenientemente arrumadas - ou da maneira que ele vier a considerar como a melhor que pôde encontrar -, talvez ele experimente um momento de exaustão, de apaziguamento, de absolvição e de qualquer coisa muito parecida com aniquilamento, que será, ela própria, indescritível. E então poderá dizer ao poema: "Vai-te! Procura lugar num livro - e não esperes que eu me torne a interessar por ti” (ELIOT, 1998, p. 112).

Há, portanto, um descompasso pressuposto na primeira voz de Eliot. Se ela também pode ser caracterizada pelo emprego de um esforço no trabalho com as palavras, o poema produzido tanto é quanto não é aquele que o poeta se põe a escrever, dado que, "quando se encontram as palavras que a expressam, aquela 'coisa' para a qual se procuram palavras desapareceu, substituída por um poema" (ELIOT, 1998, p. 111). O desaparecimento do incômodo - força motriz para a escrita do poema - talvez implique, no limite, o desaparecimento da origem da voz e a sua transformação em um efeito poético. Tomando o autor do poema não mais como a origem, mas como um sujeito que desaparece, dando lugar a um eu lírico que é um efeito de voz produzido pelo poema que escreve, a primeira voz de Eliot é atravessada pela terceira, proferida por um personagem fictício, e pela segunda, aquela que se emprega quando um poeta se dirige a um outro interlocutor. Portanto, nos poemas de Cesariny, ler a teoria das vozes eliotiana apoiada em termos do sujeito da enunciação e do interlocutor desejado aponta um caminho de leitura que as toma como processos de espetacularização e dramatização da poesia, posto que mesmo a primeira voz, aquela que é caracterizada pelo fato de ser endereçada apenas ao próprio poeta, é empregada em um esforço de descolamento do sujeito de si mesmo, posto em marcha apenas na escrita progressiva do poema. 


\section{FALAR-SE}

Éric Benoit, em seu Dynamiques de la voix poétique, ao analisar poemas que declaram o esforço empregado no trabalho de escrita, aborda uma questão similar àquela que emerge na descrição da primeira voz de Eliot. Apesar de argumentar que " $[\mathrm{u}] \mathrm{m}$ dos aspectos essenciais da modernidade literária se liga a esse drama de uma voz que fala dentro de uma cabeça, sob a ameaça do silêncio" (BENOIT, 2016, p. 17)², o teórico francês não dará à questão da origem da voz a mesma solução de Eliot. Em sua análise de poemas produzidos desde o século XIX, na França, Benoit vê a perda da razão e a despersonalização que caracterizam a poesia moderna como uma perda, também, da certeza da origem da voz poética. Parte, assim, de versos de Verlaine - "Les choses qui chantent dans la tête [...] / D'une voix jusqu'alors inouie" (VERLAINE apud BENOIT, 2016, p. 7) -, e da constatação de que o "fundo mais tenebroso" de onde emana a voz poética é a "zona mais profunda do psiquismo que a psicanálise designará em seguida como o inconsciente" (BENOIT, 2016, p. 21). Em sua leitura de Mallarmé, afirma que "a voz que fala na poesia está livre de toda a identidade subjetiva individual justamente porque a subjetividade individual está em crise e porque ela pode abrir espaço ao puro jogo de linguagem, do significante" (BENOIT, 2016, p. 29). A emergência das palavras como produtoras de sentido significará, assim, o desaparecimento do poeta como origem elocutória e detentor de significado e verdade plenos da obra, permitindo, então, o aparecimento de um sujeito lírico não mais submetido à verdade do sujeito empírico, como parecia ocorrer na leitura da primeira voz de T. S. Eliot. O autor francês buscará um caminho de leitura da problemática da referencialidade e da ficcionalidade na poesia que não considere "o eu pessoal referencial e o eu lírico fictício como categorias fixas" (BENOIT, 2016, p. 80), tomando-os como processos "dinâmicos" que entram em jogo de maneiras distintas não apenas de acordo com o autor, mas que podem, inclusive, surgir articulados de outra forma a cada poema de um mesmo autor.

Lendo o artigo "A referência desdobrada" (2010), de Dominique Combe, Benoit parte do debate secular travado na Alemanha entre os defensores de uma poesia lírica ligada à subjetividade e à intimidade de um “eu", vinculada à "pessoa referencial e biográfica do poeta (Goethe, Dilthey)” (BENOIT, 2016, p. 79), e aqueles que defendem o “eu lírico', não referencial, puramente fictício e impessoal” (BENOIT, 2016, p. 79), que prevalecerá nas leituras de autores como Nietzsche e Benjamin. Buscando uma via "mediana" (BENOIT, 2016, p. 79), portanto, retoma o argumento de Combe segundo o qual é possível

relativizar a polaridade estabelecida pela crítica entre sujeito 'empírico' e sujeito 'lírico', entre autobiografia e ficção, entre a 'verdade' e a 'poesia', não somente porque todo discurso re- 
ferencial comporta fatalmente uma parte de invenção ou de imaginação que alude à 'ficção', mas também porque toda ficção remete a estratos autobiográficos. (COMBE, 2010, p. 123)

Benoit sugerirá, assim, que a poesia, enquanto "estado outro da linguagem, dirá preferencialmente de um estado outro do eu (via sonhada, estetizada, idealizada, mística, ou inconsciente, ou ironizada)" (BENOIT, 2016, p. 90). Por mais que a poesia possa aludir a dados objetivos acerca de experiências vividas pelo sujeito, ela dará à luz um outro que nunca dá conta, plenamente, do Eu que deseja se dizer, uma vez que é um “jogo de linguagem" posto em marcha apenas no momento em que se enuncia ou em que se põe à escrita de um poema. Nesse ponto, ao oferecer a "iniciativa às palavras", conforme propõe Mallarmé, o poeta como origem da voz sai de cena e dá lugar a um novo sujeito criado por força da enunciação poética. Abrindo esse espaço, a poesia se imbui de uma potência genesíaca, possibilidade de criar aquilo que diz à medida que o diz, isto é, de descobrir e inventar, no processo de escrita, outro de si mesmo que se interroga a respeito de sua identidade. Benoit defende, portanto, que "[o] eu lírico, por mais singular e pessoal que seja, é um eu substituível, disponível à generalização, porque ele é, de partida, 'desreferencializado' pelas metáforas e assim 'dessingularizado' e 'desassujeitado' de seu sujeito original” (BENOIT, 2016, p. 57).

No ensaio intitulado "Razão e actualidade de Gérard de Nerval", publicado originalmente em 1956, Mário Cesariny faz um inventário de citações de poetas que anunciaram sua fragmentação e proclamaram sua despersonalização, seja em prol da emergência de um outro, seja da total dissolução do eu:

"Eu sou o outro" (Gérard de Nerval). "Je, est un autre." (Rimbaud). "Eu não sou eu / Eu não nasci ainda!" (Teixeira de Pascoaes). "Ah, poder ser tu, sendo eu!" (Fernando Pessoa em estado de labirinto, como se efectivamente tivesse conhecido o outro). "Eu não sou eu nem o outro" (Mário de Sá-Carneiro). "Não há na terra um único ser humano capaz de se declarar, com toda a certeza, quem é. Ninguém sabe o que veio fazer a este mundo, a que correspondem os seus actos, os seus sentimentos, as suas ideias, nem qual é o seu nome verdadeiro." (Léon Bloy, citado por Borges) (CESARINY, 1985, p. 51).

No ano seguinte, 1957, Cesariny publica o livro Pena capital, obra em que dá continuidade a um projeto de definição de sua poética iniciado com Corpo visível (1950). Entre poemas antológicos, encontra-se "autografia I", o qual parece retomar o tema da crise da figuração autoral presente na colagem de citações feita em 1956. Seu título anuncia, de partida, a coincidência entre a escrita de um corpus e a fundação de um corpo, fazendo com que o "homem-poeta" seja tanto o "autógrafo" quanto o "autografado": 
autografia I

Sou um homem

um poeta

uma máquina de passar vidro colorido

um copo uma pedra

uma pedra configurada

um avião que sobe levando-te nos seus braços

que atravessam agora o último glaciar da terra

O meu nome está farto de ser escrito na lista dos tiranos:

condenado à

[morte!

os dias e as noites deste século têm gritado tanto no meu peito que existe nele uma árvore miraculada

tenho um pé que já deu a volta ao mundo

e a família na rua

um é loiro

outro é moreno

e nunca se encontrarão

conheço a tua voz como os meus dedos

(antes de conhecer-te já eu te ia beijar a tua casa)

tenho um sol sobre a pleura

e toda a água do mar à minha espera

quando amo imito o movimento das marés

e os assassínios mais vulgares do ano

sou, por fora de mim, a minha gabardina

e eu o pico do Everest

posso ser visto à noite na companhia de gente altamente sus-

peita

e nunca de dia a teus pés florindo a tua boca

porque tu és o dia porque tu és

a terra onde eu há milhares de anos vivo a parábola

do rei morto, do vento e da primavera

Quanto ao de toda a gente - tenho visto qualquer coisa

Viagens a Paris - já se arranjaram algumas.

Enlaces e divórcios de ocasião - não foram poucos.

Conversas com meteoros internacionais — também, já por cá [passaram.

Eu sou, no sentido mais enérgico da palavra

uma carruagem de propulsão por hálito

os amigos que tive as mulheres que assombrei as ruas por

onde passei uma só vez

tudo isso vive em mim para uma história

de sentido ainda oculto

magnífica irreal

como uma povoação abandonada aos lobos

lapidar e seca

como uma linha férrea ultrajada pelo tempo

é por isso que eu trago um certo peso extinto

nas costas

a servir de combustível 
e é por isso que eu acho que as paisagens ainda hão-de vir a ser escrupulosamente electrocutadas vivas

para não termos de atirá-las semi-mortas à linha

E para dizer-te tudo

dir-te-ei que aos meus vinte e cinco anos de existência solar estou em franca ascensão para ti O Magnífico

na cama no espaço duma pedra em Lisboa-Os-Sustos e que o homem-expedição de que não há notícias nos jornais nem

[lágrimas à porta das famílias

sou eu meu bem sou eu partido de manhã encontrado perdido entre

[lagos de incêndio e o teu retrato grande! (CESARINY, 2004, p. 36-38).

No título do poema acima, "autografia I", é possível ler o apagamento da raiz [-bio] de "autobiografia", expressão que pressupõe a possibilidade de se fazer coincidir, em um mesmo plano, a experiência vivida por um indivíduo e a escrita, e que estabelece entre estas uma relação hierárquica em que a primeira assume o protagonismo temático. A palavra que dá título ao poema recusa, assim, a vinculação imediata do sujeito poético à biografia de um "eu empírico", sugerindo que é justamente a possibilidade de se escrever, de grafar-se a si mesmo, o que garantirá a emergência desse sujeito. Alia-se a isso a numeração em romanos ao lado da expressão, dando a entender que esta é apenas uma possibilidade de autografia entre outras quatro publicadas na primeira edição de Pena Capital. O fato de ser "um homem / um poeta", portanto, por mais que estabeleça uma relação referencial com o autor que escreve o poema (Mário Cesariny de Vasconcelos, indivíduo do sexo masculino cujo ofício principal foi, durante muitos anos, o de poeta - e cujo nome está escrito na capa do livro onde se encontra o poema "autografia I", acima do título que o condena à pena de morte, a "pena capital", e que reproduz aquilo que vem anunciado no verso "O meu nome está farto de ser escrito na lista dos tiranos: condenado à morte!"), será ultrapassado no verso seguinte ao se descrever como "poeta", como se esse trabalho autorizasse a transfiguração constante que desenvolve no poema. Não pretende, assim, construir uma imagem nítida de si, numa recusa da representação autobiográfica que evita uma "autorrepresentação" em favor de uma "autoapresentação" caleidoscópica, em que "dizer tudo" não equivale a dar de si uma visão totalitária, mas infinitamente múltipla. Os enunciados predicativos a respeito de si mesmo ("Eu sou X”) não formarão uma imagem única desse sujeito, antes significarão a impossibilidade de se dar dele uma visão total.

A aproximação dos afixos "auto" e "grafia", no título, ecoa, ainda, um termo caro aos surrealistas: a escrita (grafia) automática. Apresentado por André Breton no "Manifesto do Surrealismo", de 1924, o jogo de escrita automática representa uma tentativa de burla à censura do pensamento 
consciente sobre um "murmúrio", uma outra voz, que é calado no estado cotidiano de vigília e de atenção. Em seu pequeno "manual" de escrita automática, Breton recomenda:

Ponham-se no estado mais passivo, ou receptivo que puderem. [...] Façam abstração de seu gênio, de seus talentos e dos de todos os outros. [...] Escrevam depressa, sem um assunto preconcebido, bastante depressa para não conterem e não serem tentados a reler. [...] Continuem até quando quiserem. Confiem no caráter inesgotável do murmúrio. (BRETON, s/d, pp. 194-195)

No poema de Cesariny, os versos curtos e simples da primeira estrofe, que asseguram um ritmo pausado, darão lugar, sucessivamente, a longas frases cujo ponto máximo se encontra na complexa estrofe final. Desfazendo sua versificação, ler-se-ia: E para dizer-te tudo, dir-te-ei que aos meus vinte e cinco anos de existência solar estou em franca ascensão para ti O Magnífico, na cama, no espaço de uma pedra, em Lisboa-Os-Sustos, e que o homem-expedição de que não há notícias nos jornais nem lágrimas à porta das famílias sou eu meu bem sou eu partido de manhã encontrado perdido entre lagos de incêndio e o teu retrato grande!. Dita num fôlego único, num ritmo acelerado e com um volume crescente, a estrofe final é o ápice do acúmulo de descrições que vem se anunciando desde os primeiros versos. O efeito de frenesi sonoro, especialmente perceptível no dístico final, é reforçado, ainda, pela exclamação que fecha o poema, dando-lhe um "efeito de voz" (BENOIT, 2016) da cena em que esse sujeito fala a um outro e pretende se apresentar.

O poema se estrutura como uma cena enunciativa em que o eu lírico se dirige a um "tu”. Se a interlocução é a base sobre a qual se apoia, o "tu" a quem o sujeito se endereça está ativamente implicado no processo de "trans/configuração" que se opera. Nesse sentido, a emergência de um sujeito é fundamentalmente dependente de um outro a quem se deve falar. Nos sexto e sétimo versos da primeira estrofe, percebe-se o caráter performático da cena que é desenvolvida progressivamente no poema. $\mathrm{O}$ "tu", para além de poder ser endereçado a um sujeito específico que não o leitor, passa a ser, no "agora" que se anuncia, aquele que se põe a ler e que tem os olhos sobre a página, isto é, o leitor que se encontra no "agora" da leitura de "autografia I" e é, por efeito dela, transportado para dentro do poema para que atravesse "o último glaciar da terra". Ocorre, assim, que o "homem-poeta", ao recusar uma representação autobiográfica - que veria apenas sua "gabardina" - e ao propor uma apresentação de si no processo de escrita do poema e de endereçamento a um "tu", funda um outro sujeito que é, por dentro de si, "o pico do Everest". No "agora" do poema, como descrito por Benoit (2016, p. 96), "a temporalidade da experiência passada vem se fundir à temporalidade presente da escrita, ao 'aqui-sempre-aqui' da escrita [...]. O vivido autobiografado é, então, o mesmo da enunciação, 
contemporâneo do ato de escrever". Na interpelação ao leitor e no anúncio de que o poema é um "agora", o texto de Cesariny atravessa uma fronteira ficcional que se estabelece entre espectador e espetáculo, como uma quebra da quarta parede que, no teatro, funciona como garantia do status meramente voyeurístico do público, conforme assinala Patrice Pavis (2011, p. 316). Com o anúncio da emergência de um sujeito que proclama "eu sou, no sentido mais enérgico da palavra", o poema assume um caráter performático, instaurando um momento eternamente presente de escrita e de leitura, que é reforçado, ainda, pelo emprego de verbos sempre no presente do indicativo. O sujeito que se apresenta encontra-se nas palavras finais de Dominique Combe, as quais defendem que a característica fundamental do sujeito lírico reside no fato de estar em constante "tensão" entre os polos referencial e ficcional. Não se trata de buscar uma solução dialética entre os dois planos, mas de perceber como essa tensão faz com que o sujeito lírico nunca esteja "acabado". Assim,

longe de exprimir-se como um sujeito já constituído que o poema representaria ou exprimiria, o sujeito lírico está em permanente constituição, em uma gênese constantemente renovada pelo poema, fora do qual ele não existe. $\mathrm{O}$ sujeito lírico se cria no e pelo poema, que tem valor performativo. (COMBE, 2010, p. 128)

A potência criadora e transformadora do estado ordinário do "real quotidiano" que Cesariny outorga à palavra poética em sua obra volta-se, assim, para o próprio poeta que tem o seu corpo transformado a cada novo verso. A escrita de Cesariny encontra, nesse ponto, o que Pavis caracteriza como o discurso dramático em "sua força performática, seu poder de, simbolicamente, levar a cabo uma ação" (PAVIS, 2011, p. 103). O transbordar da arte na vida é uma maneira de atravessar fronteiras e de dissolver os opostos, na intenção surrealista de "fundir num só total delirante, 'explosivo-fixo,' 'solene-circunstancial', todas as presenças, ligando estreitamente a coisa a possuir e os meios de possuí-la" (CESARINY, 1997, p. 89).

\section{REFERÊNCIAS BIBLIOGRÁFICAS}

BENOIT, Éric. Dynamiques de la voix poétique. Paris: Classiques Garnier, 2016.

BRETON, André. "Manifesto do surrealismo". s/d. Disponível em: $<$ http://www.culturabrasil.org/zip/breton.pdf >. Acesso em: janeiro de 2019.

CESARINY, Mário. As mãos na água, a cabeça no mar. Lisboa: Assírio \& Alvim, 1985.

. A intervenção surrealista. Lisboa: Assírio \& Alvim, 1997.

. Poesia. Edição, prefácio e notas de Perfecto E. Cuadrado. Lis-

boa: Assírio \& Alvim, 2017. 
COMBE, Dominique. "A referência desdobrada: o sujeito lírico entre a ficção e a autobiografia”. Revista USP, São Paulo, n. 84, dez./fev. 20092010, p. 112-128.

COMPAGNON, Antoine. O trabalho da citação. Belo Horizonte: editora UFMG, 1996.

ELIOT, T. S. "As três vozes da poesia”. Ensaios de doutrina crítica. Prefácio, seleção e notas de J. Monteiro-Grillo. Lisboa: Guimarães editores, 1998, p. 95-118.

PAVIS, Patrice. Dicionário de teatro. São Paulo: Perspectiva, 2011.

Recebido para publicação em 14/11/18

Aprovado em 03/01/19

\section{NOTAS}

1 Doutoranda em Literatura Portuguesa do Programa de Pós-Graduação em Letras Vernáculas da UFRJ.

2 Todas as citações de BENOIT, Éric. Dynamiques de la voix poétique. Paris: Classiques Garnier, 2016, foram traduzidas por nós. 